\title{
Plus Marketing Mix Model and Buying Decision Of Consumer Loyalty
}

\author{
Taufik Bustami ${ }^{1}$, M. Risal ${ }^{2}$, Muhammad Aqsa ${ }^{3}$ \\ \{taufikb@student.umpalopo.ac.id ${ }^{1}$, mrisal@umpalopo.ac.id² ${ }^{2}$, muhammadaqsa@umpalopo.ac.id ${ }^{3)}$ \\ Postgraduate of Management, Universitas Muhammadiyah Palopo \\ Jalan Jendral Sudirman Km. 3. Binturu Kota Palopo, 91922, Indonesia ${ }^{123}$
}

\begin{abstract}
Cafe Paris is a restaurant that serves fast food and drinks of various types ranging from fruits to packaged drinks. To make improvements and business development, restaurant owners have made changes in anticipating competition in the growing restaurant business in Palopo City. The proposed variable plus marketing mix model, namely: (product, price, promotion, distribution, person, location), buying decisions, will have an impact on consumer loyalty in Paris Cafes.

This study aimed to get information about; a) information on the plus marketing mix model at Paris Cafe restaurants; b) information on buying decisions for Paris Cafe restaurants; c) information on consumer loyalty of Paris Cafe restaurants). The object of this research was Cafe Paris Tanjung Ringgit restaurant, Wara Timur District, Palopo City. The approach used in this research was descriptive and verification. The method used was explanatory research with a simple random sampling technique of a sample of 81 respondents. The data analysis technique used was multiple linear regression with the help of computer software SPSS 21.0 for windows. The results show the plus marketing mix model had a direct influence on the buying decision variable by 0.049 , the plus marketing mix model plus had a direct effect on the consumer loyalty variable by 0.082 . Outline, plus marketing mix model variables has effect on consumer loyalty, so does the buying decision variable has an influence on consumer loyalty at Paris restaurant in Palopo City.
\end{abstract}

Keywords: plus marketing mix, buying decisions, consumer loyalty

\section{Introduction}

The business sector that has growth potential that can sustain the national economy is the food and beverage industry. This sector is predicted to contribute and significantly to increase gross domestic product (GDP) as a non-oil and gas industry and is considered to be able to increase the realization of countryl income. "For this reason, the government continues to maintain the availability of raw materials needed by the food and beverage industry to be more productive and globally competitive. Moreover, this sector is based on added value so that the downstream process needs to be guaranteed".

The contribution of the food and beverage industry to the GDP of the non-oil and gas industry reached 34.95 percent in the third quarter of 2017, according to the Ministry of Industry in its report. These performance results make the sector the largest contributor to industrial GDP compared to other subsectors. SIn addition, the increase experienced a growth of four percent over the same period in 2016. While, the contribution to national GDP was 6.21 percent in the third quarter of 2017 or grew 3.85 percent compared to the same period the previous year. (https://kemenperin.go.id/artikel/diakses 04 Juli 2020, jam 11:08). [1] 
Restaurant and beverage business is a business that is always running. This business can be found in every region or place and is needed by anyone because all humans need food and drink. Based on the current situation, the restaurant business is a very good business and provides many benefits. Some people want to have a restaurant, both temporary and permanent because the restaurant has good prospects. Restaurants are also referred to as restaurants in Indonesia. Restaurant is an absorption word, derived from the French language adapted by English namely restaurant, derived from the word restaurer, which means to restore).[2]

\section{Literature Review}

According to [3] A marketing mix is a set of activities consisting of advertising, sales promotion, public relations, personal selling, and direct marketing tools that companies use to communicate persuasively about customer value and build customer relationships.

Swastha and Handoko state that "the buying decision process in real purchases, whether to buy or not". Kotler and Keller suggested that consumer buying decisions become a step where consumers can also form an intention to buy the most preferred product, where consumers are able to decide and modify, delay, or avoid being strongly influenced by perceived risk.

Customer loyalty is a significant intangible asset for some companies [4]. Marketing scholars have given different conceptualizations to customer loyalty [5]. Different definitions of customer loyalty are adopted by marketing researchers based on the objectives and research context. For example, [6] conceptualize customer loyalty as "a feeling of interest in someone's loyalty object, rather than repeated commercial transactions". [7] defines attitude loyalty as the customer's intention to remain consistent with certain providers in the market by repeating buying experience. In addition, Oliver defines customer loyalty as "a firm commitment to repurchase or patronize selected products / services consistently in the future, resulting in repeated purchases of the same brand or set of brands, apart from situational influences and marketing efforts that have the potential to cause switching behavior". A literature review reveals that many marketing scholars have adopted Oliver's definition of customer loyalty [8].

The problem faced by Paris Café restaurants at this time is the high level of competition for restaurants that are present in Palopo City and offer new concepts in service, menu, and competitive prices. The research contribution is to provide information to the Municipal Government of Palopo and further research on the same topic and variables that have not been researched by the authors.

\section{Method}

Penelitian ini menggunakan metode purposive sampling untuk memperoleh data dari responden. Pertanyaan dalam kuesioner disusun dari indikator variabel dependen dan variabel independen. Teknik pengumpulan data adalah denganmberinteraksi langsung dengan responden yang memiliki pekerjaan tetap maupun tidak tetap. This study applied a purposive sampling method to obtain data from respondents. Questions in the questionnaire are composed of indicators dependent variables and independent variables. The data collected by interacting directly with respondents who have permanent or non-permanent jobs. The samples in this study were 81 customers of Cafe Paris who live in Palopo City and then became respondents.

According to [9], validity is a condition that describes the ability of an appropriate 
instrument to measure what will be measured. Next, [10], reliability shows the extent to which the results of measurement instruments can be trusted. The measurement results must be reliable in terms of having a level of consistency and stability. Variables can be labeled reliably when they exceed 0.6 from Cronbach's Alpha.

\section{Result And Discussion}

Restaurants (Cafes Paris) in Palopo City is one of restaurant that serves a typical food menu located in Palopo City, Tanjung Ringgit. The advantage of this restaurant is that it is located in the harbor area which has a beautiful beach panorama.

Based on the results of the questionnaire distributed by researchers and has been processed by multiple linear regression methods with the help of SPSS 21.0 computer software, the following results are obtained:

\begin{tabular}{|c|c|c|c|c|c|c|}
\hline \multirow{2}{*}{\multicolumn{2}{|c|}{ Model }} & \multicolumn{2}{|c|}{$\begin{array}{c}\text { Unstandardized } \\
\text { Coefficients }\end{array}$} & \multirow{2}{*}{$\begin{array}{c}\text { Standardized } \\
\text { Coefficients } \\
\text { Beta } \\
\end{array}$} & \multirow[t]{2}{*}{$\mathrm{t}$} & \multirow[t]{2}{*}{ Sig. } \\
\hline & & $\mathrm{B}$ & Std. Error & & & \\
\hline \multirow[b]{2}{*}{1} & (Constant) & 16.206 & 2.061 & & 7.864 & .000 \\
\hline & Plus Marketing Mix (X1) & .071 & .079 & $\begin{array}{l}.029 \\
-228\end{array}$ & .251 & .802 \\
\hline
\end{tabular}

a. Dependent Variable: Consumer Loyalty (Y)

Multiple linear regression analysis is used to look for a direct relationship between the independent variable marketing mix (X1) and buying decision (X2) with the dependent variable of consumer loyalty (Y). The results can be explained as follows: plus marketing mix variable has a strong influence of 0.071 . This shows the influence of the plus marketing mix on consumer loyalty, plus marketing mix has a positive coefficient value, meaning that if there is a marketing performance plus it will increase consumer loyalty in the restaurant (Paris Cafes) in Palopo City.

Furthermore, the buying decision variable also has a strong influence on consumer loyalty of 0.084 . This shows the influence of the buying decision has a positive coefficient, meaning that if the buying decision performance increases will increase consumer loyalty.

Table 2. Model Summary

\begin{tabular}{ccccc}
\hline Model & R & R Square & $\begin{array}{c}\text { Adjusted R } \\
\text { Square }\end{array}$ & $\begin{array}{c}\text { Std. Error of the } \\
\text { Estimate }\end{array}$ \\
\hline 1 & $.747^{\mathrm{a}}$ & .619 & .663 & .770 \\
\hline
\end{tabular}

a. Predictors: (Constant), Plus Marketing Mix (X1), Buying Decision (X2)

Based on the calculation above, the coefficient of determination (Adjusted R2) is obtained which is 0.663 . It means that the correlation between marketing mix plus consumer loyalty to Restaurant (Paris Café) Palopo City can be explained by 66.3 percent while the remaining 33.7 percent is influenced by other factors not examined in this study.

This research results are in line with the results of research conducted by [11] who states that the plus marketing mix influences consumer loyalty, then [12] states the buying decision also affects consumer loyalty to organic products in Bogor City. 


\section{Conclusion}

a) Multiple linear regression analysis is used to find a direct relationship between the independent variable marketing mix $\left(\mathrm{X}_{1}\right)$ and purchase decision $\left(\mathrm{X}_{2}\right)$ with the dependent variable consumer loyalty $(\mathrm{Y})$, the results can be explained as follows: the marketing mix plus variable has a strong influence of 0.071 . This shows the effect of the plus marketing mix on consumer loyalty, the plus marketing mix has a positive coefficient value, meaning that if there is a marketing performance plus it will increase consumer loyalty to the restaurant (Paris Café) in Palopo City.

b) Furthermore, the purchasing decision variable also has a strong influence on consumer loyalty by 0.084 . This shows the effect of purchasing decisions has a positive coefficient value, meaning that if the performance of purchasing decisions increases, it will increase consumer loyalty.

\section{Acknowledgments}

Dr. Muhammad Aqsa, S. Kom. M. Si., For his knowledfe and guidance so that this article can be finished.

\section{References}

[1] (https://kemenperin.go.id/artikel/diakses 04 Juli 2020, jam 11:08).

[2] Utami NDPA, Citrakesumasari dan St. Fatimah. Kandungan Zat Gizi Makro dan Pengaruh Bumbu terhadap Angka Peroksida per Porsi Coto Makassar. http://repository.unhas.ac.id/handle/123456/. Diakses tanggal 12 Maret 2014

[3] Kotler, Philip \& Gerry Armstrong, (2014): Principle Of Marketing, 15th edition. New Jersey: Pearson Pretice Hall.

[4] Jiang dan Zhang, 2016. An investigation of service quality, customer satisfaction and loyalty in China's airline market. Journal of Air Transport Management 57 (2016) 80-88

[5] Ali, et al. 2015. Tourism Marketing. Center for Academic Publishing Service. Yogyakarta.

[6] Casidy dan Wymer, 2016. A risk worth taking: Perceived risk as moderator of satisfaction, loyalty, and willingness-to-pay premium price. Journal of Retailing and Consumer Services 32. 189-197

[7] Thakur, R. (2016). Understanding customer engagement and loyalty: a case of mobile devices for shopping. Journal of Retailing and Consumer Services, 32

[8] Haryanto et al. 2016. Pengaruh Kualitas Produk, Kualitas Layanan, Nilai Nasabah Terhadap Citra Perbankan Serta Implikasinya Pada Keputusan Nasabah Menabung Dengan Karakteristik Nasabah Sebagai Variabel Moderating Pada Perbankan Syariah di Madura. Volume 1, Nomor 1, Oktober 2016.

[9] Arikunto, Suharsimi, 2010. Prosedur Penelitian Suatu pendekatan Praktek. Jakarta: Rineka Cipta. 
[10] Nugroho John, 2011. It's Easy Olah Data Dengan SPSS. Yogyakarta.

[11] Minto Waluyo, 2011. Modifikasi Model Bauran Pemasaran Plus Terhadap Variabel Pembentuk Yang Positif dan Signifikan. Jurnal Teknik Industri, Vol. 12, No. 1. 20-26

[12] Tantry Nugroho, Ujang Sumarwan, and Kirbrandoko, 2015. Factors Influencing The Purchase Decision of Organic Tofu. Available online at http://journal.ipb.ac.id/index.php/ijbe. 